NB: This conference paper is a draft chapter for a book-length manuscript. Please do not cite without permission.

\title{
Chapter 3: The New Deal: Retrospection, Realignment, or a Reconstituted Polity?
}

\begin{abstract}
Roosevelt is the only president we ever had that thought the Constitution belonged to the pore man too. The way they've been areadin' it it seemed like they thought it said, 'Him that's got money shall have the rights to life, freedom and happiness.'. . . Yessir, it took Roosevelt to read in the Constitution and find out them folks way back yonder that made it was talkin' about the pore man right along with the rich one.
\end{abstract}

-George Dobbin ${ }^{1}$

Political scientists and constitutional theorists agree that the New Deal represents a significant change to American life, but they disagree as to why. Realignment scholars argue 1932 was a critical election that reoriented the makeup and agendas of the two parties. New constituencies formed around each party according to support for their respective policies. ${ }^{2}$ Recently, Christopher Achen and Larry Bartels offered a more pessimistic interpretation of the political legacy of this era: voters engaged in "myopic retrospection" and grew to support the New Deal only because it succeeded. Conventional realignment accounts, they argue, "overstate the extent to which Depression-era voters weighed and endorsed the specific policies of the Roosevelt administration." ${ }^{3}$ Legal academicians, by contrast, view the New Deal as constitutionally significant because it marked a turning point in the Supreme Court's jurisprudence on federal regulatory power. ${ }^{4}$ One theory of constitutional development, proposed by Bruce Ackerman, contends that ordinary Americans played a role in this legal transformation.

Until now, data limitations and differences in methodological preferences have kept these literatures out of conversation with each other. In this chapter, I provide a first attempt at evaluating the relative persuasiveness of the traditional realignment, economic retrospection, and constitutional development theories of the New Deal. I leverage early Gallup polls that gauged public opinion on specific New Deal policies, proposed constitutional amendments, and economic perceptions. These surveys, along with data on state income growth, allow for a

\footnotetext{
${ }^{1}$ These Are Our Lives: As Told to by the People and Written by Members of the Federal Writers' Project of the Works Progress Administration in North Carolina, Tennnesse, and Georgia, 210-11.

${ }^{2}$ Burnham, Critical Elections; Caughey, Dougal, and Schickler, "Policy and Performance in the New Deal Realignment"; Key, "A Theory of Critical Elections."

${ }^{3}$ Achen and Bartels, Democracy for Realists, 181; See also Norpoth, Sidman, and Suong, "Polls and Elections."

${ }^{4}$ Corwin, Constitutional Revolution, Ltd.
} 
comparisons between the different theories of realignment from political science and Ackerman's theory of dualist democracy.

Across 19 surveys, attitudes towards New Deal social, economic, and foreign policies consistently provide stronger predictions of presidential job approval and vote intention than models of economic voting. Thus, I find little evidence to support the Achen Bartels thesis that Americans supported the New Deal only because it worked. Determining if citizens were ratifying a change in economic policy or a change to the constitutional status quo is more challenging. The pro-court-packing letters analyzed in Chapter 6 provide more direct evidence on this question.

Because of data limitations, this chapter takes a more inductive approach. I analyze congressional rhetoric during the House floor debate on the Fair Labor Standards Act of 1938, which established wage and work hour regulations. Despite the fact that Congress passed the law in the middle of the "Roosevelt Recession," opponents of the bill largely avoided arguments about the sluggish economy. Instead, opponents (and supporters) more frequently engaged in constitutional arguments about commerce and federalism. These arguments may have penetrated the broader public conversation. Most New Deal policies - even those struck down by the Supreme Court - enjoyed broad, bipartisan support, as did several proposed constitutional amendments to expand federal power. The similarity in findings provides initial evidence that many Americans viewed the New Deal as a constitutionally-significant change.

\section{American Mass Politics: One or Two Tracks?}

Political scientists have described the relationship between the political and policy changes of the 1930s in slightly different ways. Changes to party coalitions occur during critical elections, which some scholars define as a tipping point, ${ }^{5}$ while others think of as a punctuated equilibrium. ${ }^{6}$ Social groups emerge out of realignment with new partisan loyalties as a result of self-interest, ideological commitments. ${ }^{7}$ However the electoral changes occur, they produce policy consequences based on voter preferences. According to V.O. Key, "By 1936 the innovative period of the New Deal had pretty well run its course, and in that year voters

\footnotetext{
${ }^{5}$ Key, "A Theory of Critical Elections."

${ }^{6}$ Burnham, Critical Elections.

${ }^{7}$ Ladd and Hadley, Transformations of the American Party System; Sundquist, Dynamics of the Party System.
} 
responded with a resounding ratification of the new thrust of governmental policy. Or, if one wishes to be cautious, the electorate soundly rejected the Republican alternative, which, as the campaign of 1936 developed, appeared to be a hysterical plea to return to the pre-1932 status quo lest the American system become a dictatorship." 8

Bruce Ackerman goes even further, claiming the New Deal was a constitutional moment in which the American people understood and authorized an informal change in constitutional law. ${ }^{9}$ To Ackerman, there was nothing pathetic about Alf Landon's campaign message, as two different constitutional visions were effectively on the ballot for the people to evaluate. Ackerman's understanding of the effectiveness of voting behavior also differs radically from traditional accounts in political science. According to Ackerman, American constitutional development operates on two tracks: normal politics and periods of higher lawmaking. Citizens and elected officials operate under fundamentally different obligations on each track.

During periods of normal politics, citizens are largely disengaged, and elected officials have the authority to make decisions on their behalf within the ideological constraints of the regime. A regime jumps the bounds of normal politics and enters a period of higher lawmaking if different branches of the government reach an impasse about the regime's core commitments. A decisive election provides the legitimacy needed for a reformist coalition to prevail over a resistant branch of government. ${ }^{10}$

Constitutional moments, which occurred during the Founding, Reconstruction, as well as the New Deal, mark the successful completion of a period of higher lawmaking. In order for popular sovereignty to create a constitutional moment, citizens must engage in unusually deep levels of deliberation. Ackerman expects a citizen to have deliberated "as much about her commitment to a national ideal as she thinks appropriate in making a considered judgment on an important decision in her private life." 11 Deliberation must focus on the costs and benefits of a proposed constitutional change to the polity, not just one's self or political party.

During normal politics, Ackerman argues citizens "are under no illusions about the quality of reflection that lie behind" their vote choices. ${ }^{12}$ Instead, citizens pursue other

\footnotetext{
${ }^{8}$ Key, The Responsible Electorate, 33. To be fair to Alf Landon, only his running mate, Frank Knox, who engaged in histrionics on the campaign trail. Shesol, Supreme Power, 236.

${ }^{9}$ Ackerman, Foundations; Ackerman, Transformations.

${ }^{10}$ Ackerman, Transformations, 20.

${ }^{11}$ Ibid., 274.

12 Ibid., 241.
} 
conceptions of the good life that deemphasize the political to make time for "sport or science or religion, friends and family and the business of life." 13 This language appears eerily similar to that used by Achen and Bartels at the beginning of their critique of engaged citizenship. "Human beings are busy with their lives," these authors write. "For most, leisure time is at a premium. Sorting out which presidential candidate has the right foreign policy toward Asia is not a high priority for them." 14

From a normative standpoint, dualist democracy allows citizens to shirk the duty of formulating foreign policy, except perhaps some policy that clearly goes beyond the scope of regime commitments. It is one thing to debate the relative merits of holding China accountable for human rights violations versus improving trade relations. It is quite another if a president called for the recolonization of the Philippines, a prominent ideological commitment of the preNew Deal regime. ${ }^{15}$

From an empirical perspective, dualist democracy holds that citizens are not incapable of engaging in deliberation if called upon. By contrast, most voting behavior scholars would argue policy issues are too complex for voters to understand, no matter how much effort they expend. Instead, it is more realistic for citizens to use shortcuts, like partisanship, to determine their issue preferences. Before dismissing the possibility of a more engaged citizenry, it is important to remember that political scientists did not perfect sampling techniques until after the New Deal became an accepted part of American political life. Every American National Election Study, which formed the empirical basis for The American Voter and its progeny, reflected a polity with a constrained scope of political contestation. ${ }^{16}$ Thus, Ackerman's theory has not yet been adequately tested because political scientists have almost exclusively analyzed data from the long period of normal politics following the New Deal constitutional moment.

Without analyzing data from the 1930s, political scientists can easily underestimate the stakes of the New Deal revolution. Consider the 2012 Republican primaries, when former Texas Governor Rick Perry called for the elimination of three cabinet departments. Journalists at the time described this plan as "extremist." 17 Yet, Perry could only remember the names of two of

\footnotetext{
13 Ibid., 231.

${ }^{14}$ Achen and Bartels, Democracy for Realists, 9.

${ }^{15}$ For an account of the ideology justifying American colonization, see Sparrow, The Insular Cases.

${ }^{16}$ Campbell et al., The American Voter.

17 "The Republicans: A Dangerous Game."
} 
the departments he wanted to abolish during a debate, which caused him, the other candidates, and the audience to laugh. ${ }^{18}$ To the Republican Party of the 1930s, this would be no laughing matter. Since the New Deal, Congress has created seven new cabinet departments and seven cabinet-level agencies. The ancien Republican regime, which governed from Reconstruction through 1932, would view the existence of almost all these entities as unconstitutional, not merely unwise. From this perspective, Perry's proposal to eliminate only three of fourteen seems quite restrained.

Ultimately, neither Achen and Bartels nor Ackerman provide sufficient evidence to support their claims about the New Deal. According to Achen and Bartels, voters engaged in a series of retrospective economic evaluations, meaning Roosevelt and Democrats in Congress gained voters in states with recent gains in income growth and lost them is less prosperous states. However, their analysis of New Deal era votes contain no direct measures of policy attitudes. The closest they can come is measuring state-level demographic characteristics. At best, one could infer that certain groups in the New Deal coalition would be more likely to favor liberal policies and, therefore, support Democrats at the polls. Nevertheless, they cannot provide a direct test for their claim that the economy provides a better explanation for the New Deal realignment than existing policy-based theories.

The second problem is that Achen and Bartels use state-level election results, rather than individual-level attitudes. ${ }^{19}$ By inferring individual-level attitudinal conclusions from aggregatelevel data, the analysis engages in ecological fallacy. ${ }^{20}$ Sometimes analyses at these two levels of analyses will yield similar findings, but other times they will not. For example, at the individual level, wealthier individuals tend to vote for Republicans, yet voters in wealthier states tend to vote for Democrats. It could be the case that certain groups of voters were more likely to support Democrats during the 1930s-1940s because of their policy attitudes than the economic environment, one cannot be sure.

\footnotetext{
${ }^{18}$ Perry sought the Republican nomination again in 2016, but this time he wore glasses, which critics argued was an attempt to reclaim the gravitas lost by his prior forgetfulness. Ironically, Perry would go on to become Donald Trump's Secretary of Energy, the department whose name eluded him five years earlier. Reilley, "Rick Perry."

${ }^{19}$ Caughey, Dougal, and Schickler use the same unit of analysis to argue policy preferences as well as economic trends structured the New Deal realignment. Caughey, Dougal, and Schickler, "Policy and Performance in the New Deal Realignment."

${ }^{20}$ See Kramer, "The Ecological Fallacy Revisited."
} 
Most of Ackerman's analysis focuses on the actions of political elites during the New Deal, which is odd considering dualist democracy uses citizens as its unit of analysis. For proof of a New Deal constitutional moment, Bruce Ackerman simply points to the Democratic Party's vote shares in the 1930s. Ackerman argues, the "consistent and sustained support of the American people for the constitutional principles elaborated by New Deal Democracy through three Presidential, and six Congressional, elections," provides sufficient evidence of popular sovereignty. ${ }^{21}$ Political scientists have warned against imparting too much meaning from an election result. Voters often have uncorrelated preferences on social, economic, and foreign policies, which means they may not have a logical fit within any political party's platform. ${ }^{22}$

The data assessed by Ackerman, as well as Achen and Bartels, require a high level of inference to support any underlying theoretical claim. The data in this chapter allows for a more direct evaluation of economic- and policy-based understandings of the New Deal realignment.

\section{Comparing Policy and Economic Retrospection Models of New Deal Support}

The Roper Center for Public Opinion Research houses an archive of Gallup polls dating back to 1936. The data for this analysis come from 19 surveys conducted between September 1936 and October 1940. I included any survey that met the following criteria. First, the poll asked respondents about their approval of President Roosevelt's job performance or about their vote intentions in a congressional or presidential election. ${ }^{23}$ Second, the survey included a question about at least one policy favored or enacted by the Roosevelt administration. Finally, either the survey included a question about how respondents perceived the economy, or Gallup conducted the poll near the beginning or end of a year, in which case the analyses includes annual, state-level economic data. Table 3.1 displays the wording of every question used in the analysis.

\footnotetext{
${ }^{21}$ Ackerman, "A Generation of Betrayal," 1534.

${ }^{22}$ Stokes, "Spatial Models of Party Competition," 370; Davis, Hinich, and Ordeshook, "Mathematical Model of the Electoral Process."

${ }^{23}$ Most of the time, Gallup asked vote intention questions in the context of upcoming elections. Other times, a survey included a retrospective voting question like: "If last November's election were being held over again today, which candidate would you vote for now?" I incorporate both types of questions. Because of the unique role played by the Democratic Party in the South during this time period, analyses of congressional vote intention include only non-southern respondents. Achen and Bartels also exclude southern states from their analyses of presidential election results. Achen and Bartels, Democracy for Realists. By contrast, I include southern respondents in analyses of presidential vote intentions as the results are substantially similar to those produced by a non-southern subsample.
} 
Analyzing public opinion from the 1930s presents empirical challenges, as survey research was in its infancy. Before the creation of probability sampling, Gallup used quotacontrolled samples to approximate the voting population, which underrepresented Southerners, women, African Americans, and the poor. Scholars have found the deviations between Gallup's sample characteristics and the population were predictable and developed model-based poststratification weights to correct the differences. ${ }^{24}$ I employ a dynamic, calibrated weight that corrects biases in sampling of the mass public for presidential approval models. Analyses of vote intentions utilize a similar weight designed to replicate the voting public. $^{25}$

Gallup probed economic perceptions in different ways. Some questions required respondents to make personal, retrospective economic assessments. Other times, the poll asked for a prediction of the future economy. When subjective perceptions are not available, I utilize objective economic indicators. Specifically, I include the four most recent years-worth of changes to per capita state income in the respondents' home state, as well as a control for per capita state income in $1929 .{ }^{26}$ There has been a lengthy debate within political science about the most accurate way to measure economic voting: whether to use objective economic data or subjective perceptions; ${ }^{27}$ whether voters engage in self-interested, pocketbook assessments or broader, societal evaluations, ${ }^{28}$ and whether these evaluations are retrospective or prospective. ${ }^{29}$ While the issues raised by these scholars are important, the goal of this chapter is simply to leverage as much data as possible to investigate the nature of public support for President Roosevelt.

The policy questions in these surveys capture attitudes on various social and economic issues, as well as foreign affairs. Some issues, like Social Security, are highly salient, while others are less conspicuous. On average, policy questions had a $91.2 \%$ response rate. ${ }^{30}$ Very

\footnotetext{
${ }^{24}$ Berinsky, "American Public Opinion in the 1930s and 1940s"; Berinsky et al., "Revisiting Public Opinion in the 1930s and 1940s."

${ }^{25}$ Caughey et al., "Population Estimation and Calibration Weighting for Nonresponse and Sampling Bias."

${ }^{26}$ Like Achen and Bartels, I measure the annual change in state income as the difference in logged income from the preceding year, multiplied by 100 . Analyses using state income changes include standard errors clustered by state. Achen and Bartels, Democracy for Realists, 184.

${ }^{27}$ Kramer, "The Ecological Fallacy Revisited."

${ }^{28}$ Lewis-Beck, "Pocketbook Voting in U.S. National Election Studies"; Kinder and Kiewiet, "Sociotropic Politics."

${ }^{29}$ Fiorina, Retrospective Voting; Soroka, Stecula, and Wlezien, "It's (Change in) the (Future) Economy, Stupid."

${ }^{30}$ I wanted the analyses to focus on as wide a segment of the public as possible, not just politically attentive individuals. Consequently, I excluded policy questions with non-response rates above $30 \%$.
} 
few questions mention the president's name, and the results are substantially similar when these questions are excluded. Including the president's name in a policy question is likely increase the response rate and bias some respondents to construct their answer based on their attitude towards FDR, not the policy. ${ }^{31}$

Not all of these policies that Gallup inquired about came to fruition during Roosevelt's administration, nor were Gallup's questions perfect reflections of the administration's position. For example, Gallup asked in January 1938 whether the next Supreme Court vacancy should go to a woman. While President Roosevelt did not nominate a female justice to the Supreme Court, he did appoint Florence Ellinwood Allen to the Sixth Circuit Court of Appeals, the first woman to serve as an appellate court judge. Moreover, a recent study found Roosevelt shortlisted Judge Allen in 1938 for the nomination that eventually went to Stanley Reed. ${ }^{32}$ The only policy included in the analysis that President Roosevelt did not support was a federal ban on lynching. Nevertheless, I include it because Eleanor Roosevelt was an outspoken advocate of the bill and attempted to serve as a conduit between the president and the NAACP. ${ }^{33}$

To engage in these comparisons, I calculate pairs nearly identical statistical models and measure which performs better. One model in the pair uses an economic variable to predict some dependent variable - like presidential approval or vote intention for president or Congress. The other model swaps out the economic variable and adds a policy variable in its place. A respondent must have an opinion on the economic question and the policy question to be included in the analysis. Keeping the number of respondents in each model constant allows for a more direct comparison.

Each model also includes a set of demographic variables that may be correlated with the dependent variable. Including the same set of demographic characteristics in each model controls for potential confounding factors between the economic (or policy) variable and the dependent variable. For example, one would expect individuals who voted for President Roosevelt in 1936 to be more supportive of Social Security and more likely to approve of the president's job performance than Republican voters.

\footnotetext{
31 The results are substantially similar if I exclude policy questions that mention the president.

32 Jefferson and Johnson, Shortlisted.

${ }^{33}$ Cooper, "Reframing Eleanor Roosevelt's Influence in the 1930s Anti-Lynching Movement around a 'New Philosophy of Government.",
} 
These measures include prior electoral behavior, occupation, ${ }^{34}$ race, ${ }^{35}$ gender, age, whether the respondent is a relief recipient, region, and urban residence. Gallup did not consistently measure party affiliation, but they did ask whether (and for whom) respondents had voted in the most recent presidential election. Thus, a respondent's 1936 vote choice serves as a proxy for partisanship. The structure of this question allowed respondents to indicate they had supported a third party candidate, that they were too young to vote, or did not vote for some other reason.

Each model produces an $\mathrm{R}^{2}$ score, which measures the percentage of the variability in the dependent variable that is accounted for by the model. ${ }^{36}$ Statistical models that explain nearly all the variation in the dependent variable have $\mathrm{R}^{2}$ scores closer to one, while models that do not have strong predictive power have $\mathrm{R}^{2}$ scores closer to zero. Whichever model in the pair - the one with a policy variable or an economic variable - that has the higher $\mathrm{R}^{2}$ value provides the better explanation of support for Roosevelt or Democrats in Congress.

The data from 19 surveys allowed for 85 model comparisons, 43 involving subjective economic perceptions and 42 using objective economic indicators. In the vast majority of these models, the economic and policy variables each exert a significant influence on support for Roosevelt and Democrats in Congress. The question, however, is which approach does a better job. Table 3.2 presents the results of the $\mathrm{R}^{2}$ score comparisons generated by probit regression. In 61 of the 85 comparisons (71.8\%), the policy model outperformed the economic model, as measured by the $\mathrm{R}^{2}$ statistic.

The asterisks in Table 3.2 indicate that a particular results is unlikely to be the product of random chance. ${ }^{37}$ For example, after flipping a coin 85 times, one would expect heads to occur 42 or 43 times. However, it is possible that in a given coin flipping session, the number of heads may be somewhat smaller (or larger) than 42 or 43 . The asterisk indicates that the finding is statistically significant, or, to put it another way: one can state with $95 \%$ confidence that policy models in that particular set of comparisons outperformed the corresponding economic models.

\footnotetext{
${ }^{34}$ While the data do not specifically record what each respondent did for a living, Gallup interviewers classified a respondent's occupation into four categories: professionals, clerks, labor, and the unemployed.

35 The surveys measure race dichotomously as either white or black.

36 Technically, because I use probit regression for every comparison, the models produce Pseudo- $\mathrm{R}^{2}$ scores.

${ }^{37}$ Specifically, I performed a t-test to see which results displayed in Table 3.2 were statistically different from $50.0 \%$ at the $p<0.05$ level.
} 
When broken out by dependent variable, policy models did very well in predicting approval of and electoral support for President Roosevelt, outperforming economic models $81.5 \%$ and $71.8 \%$ of the time, respectively. Both of these results are statistically significant. By contrast, policy models were only modestly more successful than economic models in predicting congressional vote intention (57.9\%). Policy models outperformed state income changes at a statistically significant rate of $81.0 \%$. On the other hand, policy models fare better than personal economic assessments only $62.8 \%$ of the time.

The robustness of the results using objective economic indicators is noteworthy because of the nature of calculating $\mathrm{R}^{2}$ statistics. Anytime a variable is added to a model, the $\mathrm{R}^{2}$ score will always increase, regardless of how relevant the variable is in explaining a phenomenon. Models that used state income data included five variables - changes from the preceding four years and a control for state income in 1929. Those models would then be compared to models with only one policy variable in them.

Overall, citizens appear to be more motivated by their policy positions than economic considerations when determining congressional or presidential vote intentions and presidential job approval. This analysis provides little support for the "myopic retrospection" theory proposed by Achen and Bartels. However, the strength of policy attitudes in structuring support for Roosevelt and congressional Democrats does not directly confirm or disprove Ackerman's theory of dualist democracy. This theory expects citizens to become more engaged periods of constitutional change, not policy change, which begs the question as to how best to describe the mid-1930s.

It is difficult to draw such a fine distinction, however, as only a change to the constitutional order would permit the government to make dramatically different policies. If the New Deal policies represented a change from the constitutional status quo, one might expect to see Congress debating economic policy in constitutional terms. The next section provides some qualitative evidence for this hypothesis, at a time when, based on the myopic retrospection theory, one might also expect to see members of Congress to debate the New Deal in terms of its (seeming lack of) success.

The Fair Labor Standards Act and the Dog That Didn't Bite 
During the 1932 presidential campaign, Franklin Roosevelt offered few details of exactly how he planned to assist "the forgotten man." Once in office, his policies often reflected this lack of detail, which has caused many scholars to describe Roosevelt's economic philosophy as pragmatic and his constitutional vision as incoherent. ${ }^{38}$ The economic policies of the New Deal had only one thing in common: they required more power for the federal government to regulate business than the Supreme Court of the 1920s-1930s was willing to grant.

Otherwise, the New Deal had the appearance of an inductive social experiment: using trial and error to discover empirical truths about public administration. The larger research question, however, was clear to contemporary observers. "The Roosevelt experiment, in a word, is a systematic effort to put capitalism into leading strings of principle," wrote the political scientist Harold Laski in 1934. "[Capitalism] is to be the servant, and not the master, of the American people." ${ }^{39}$

Beginning in late 1937, it appeared the New Deal experiment might be failing. The unemployment rate, which had fallen to $11 \%$ in July of 1937 began to rise, as the United States fell into the "Roosevelt Recession." By April of 1938, the unemployment rate had risen to 19\%, a level that had not been seen since the end of 1934. Manufacturing output fell by more than a third between 1937 and 1938 and real gross domestic dipped by 3.3\% during the same period. The recession marked a major reversal from the $12.9 \%$ growth in GDP from the prior two years. ${ }^{40}$

Voters tend to blame incumbents for poor economic performance, regardless of whether their policies are responsible for creating a downturn. In this case, however, President Roosevelt most likely bears considerable responsibility for his eponymous recession. The 1932 Democratic platform had called for a balanced federal budget, a promise on which Roosevelt could not deliver in his first term. In 1937, Roosevelt bowed to the advice of Treasury Secretary Henry Morgenthau and cut federal spending. Keynesian economists - at the time and subsequentlypoint to the abandonment of deficit spending as a mistake. ${ }^{41}$

Gallup polls from this time indicate a more pessimistic economic and political outlook. According to an April 1938 poll, 21\% of respondents said their view of the president had

\footnotetext{
${ }^{38}$ E.g., Schlesinger, The Politics of Upheaval.

${ }^{39}$ Laski, "The Roosevelt Experiment."

${ }^{40}$ Waiwood, "Recession of 1937-38."

${ }^{41}$ Waiwood.
} 
changed since the 1936 election. According to the same survey, $61 \%$ of Americans said they were not "better off than they were a year ago." Many Americans feared the slumping economy would only get worse, as $58 \%$ described the business climate as a depression instead of a recession. ${ }^{42}$

In the spring of 1938, the House took up the Fair Labor Standards Act (FLSA), which had passed the Senate in 1937 but had been bottled up in the House Rules Committee. The bill specified an eight-hour workday and a 40-hour workweek, established a minimum wage, and required employers to pay overtime at 50\% more than the normal wage. ${ }^{43}$ Based on the "myopic retrospection" theory advanced by Achen and Bartels, one would expect conservatives to cite the Roosevelt Recession as a reason to oppose the FSLA. After years of experimentation, it was no longer clear the New Deal was working, and now the administration was asking Congress to embrace yet another bold economic reform. If the pages of the Congressional Record contained many constitutional arguments on the FLSA, it would better support the theory of dualist democracy.

The context of this debate is important for both theories: April 1938 was not only a period of economic turmoil, it also marked one year since the Supreme Court made its "switch in time." During that time, the Court upheld the National Labor Relations Act ${ }^{44}$ and the Social Security Act. ${ }^{45}$ Perhaps more significantly, Justice Willis Van Devanter, one of the conservative "Four Horsemen of the Apocolypse," had retired, and Roosevelt had replaced him with a proNew Deal liberal, Senator Hugo Black. In 1938, the country may have experienced economic uncertainty, but the Supreme Court was becoming much predictably liberal. As a result, there would be fewer incentives for members of Congress to debate the constitutionality of the FLSA compared to earlier in the Roosevelt Administration.

Although the Court was shifting leftwards, conservative Democrats in Congress had reason to feel optimistic. Many of these members had voted for New Deal programs in Roosevelt's first term based on fear, not sincerity. ${ }^{46}$ Appearing to be a loyal New Dealer meant more patronage for these members to steer to their districts and states. Fissures began to appear

\footnotetext{
${ }^{42}$ Gallup Organization, Poll 118.

${ }^{43}$ Douglas and Hackman, "The Fair Labor Standards Act of 1938."

${ }^{44}$ NLRB v. Jones \& Laughlin Steel Corp., 301 U.S. 1 (1937).

${ }^{45}$ Helvering v. Davis, 301 U.S. 619 (1937).

46 Patterson, Congressional Conservatism and the New Deal.
} 
between the liberal and conservative wings of the party when a bipartisan, ideologically-diverse coalition of senators killed the court-packing plan in July 1937. A similar bipartisan coalition of conservatives in the House banded together to defeat FDR's executive branch reorganization plan in April 1938. A month later, the House took up the FLSA.

Republican members of Congress had largely avoided making public statements on the court-packing and executive reorganization bills. When the House took up the FLSA, Republicans began to reenter the political fray. Nevertheless, only Representative Hamilton Fish (R-NY) mentioned the current recession or the Great Depression in a floor speech, and he did so in the context of announcing his support for the bill. "I believe [President Roosevelt] is solely responsible for the present depression through his economic fallacies which have destroyed business confidence and caused tragic unemployment and destitution...However, that is not the issue," Fish stated. He had opposed the Administration's version of the bill because it gave the president too much power to issue executive orders. His position changed because, "[t]he present bill, as written, sets up a uniform standard of hours and wages throughout the Nation, by law and not by bureaucracy." ${ }^{47}$

Opponents of the bill tended to offer a more complex rhetoric that intertwined parochial economic concerns with broader constitutional claims. The strongest opposition to the bill came from Southern Democrats, who feared losing their competitive advantage of cheap labor. These members feared unemployment would increase because Southern businesses would be unable to comply with a national minimum wage. The bill's most strident opponent, Representative Eugene Cox (D-GA), constitutionalized this argument. "This country," he argued, "is divided into three distinct economic and social sections, the North, South, and West." ${ }^{\text {"8 }}$ The FLSA threatened to "destroy the reserved powers of the States over their local concerns" and "wip[e] out the distinction between commerce among the several States and the internal commerce of a State." 49

Representative Maury Maverick (D-TX), a strong supporter of the bill, offered a rebuttal that also blended economic and constitutional reasoning. The South's cheap labor, according to Maverick, was the product of racial discrimination. "As a result of the incubus of the colored

\footnotetext{
${ }^{47}$ Congressional Record, 83:7297-98.

${ }^{48}$ Ibid., 7418.

${ }^{49}$ Ibid., 7420 .
} 
people who were brought there as slaves--and some of them have never really gotten out of that condition and have brought the white sharecropper to their level--the South has the lowest living standards of any part of the United States." 50 Representative John O'Connor (D-NY) compared the debate on the bill to that over Prohibition and warned his southern colleagues against constitutional hypocrisy. "I do not want any of my good friends to rise on the floor today and argue for States' rights if they were for prohibition," he said. ${ }^{51}$

While conservative members of Congress avoided references to the Roosevelt Recession, conservative interest groups did not. Amos Pinchot, the president of the National Committee to Uphold Constitutional Government, wrote an open letter to the president blaming the New Deal for America's slower economic recovery compared to nations in Europe. Here too, however, the Committee carefully paired critiques of economic performance to Roosevelt's disruption of constitutional norms. Pinchot wrote, "Like the dictators of Europe, you have demanded more power as you have been given more. You have gained an ever-tighter grip on Government, business, labor, and agriculture. Wages must be fixed by the Executive, hours must be fixed." 52 Pinchot and the Committee had played a pivotal role in the court-packing and executive reorganization defeats, but they could not replicate their success on the FLSA. The House roll call looked similar to votes from Roosevelt's First 100 Days: many conservatives held their noses and voted for it. This evidence is consistent with the findings from the previous section: members of Congress who were ideologically out-of-step with their constituents realized support for the New Deal back home mattered more than the economy.

But what about the constitutional arguments made during the congressional debate on the FLSA? Was this a rhetorical strategy targeted at persuading other members of Congress, or did these arguments resonate with voters outside of Washington? The final section of this chapter seeks to answer these questions by analyzing public opinion data from earlier in the Roosevelt presidency.

Constitutionalizing the Expansion of Federal Power

\footnotetext{
${ }^{50}$ Congressional Record, 83:7292.

${ }^{51}$ Ibid., 7278.

52 Ibid., 7157.
} 
“Today," Attorney General Homer Cummings remarked in his diary, "was a bad day for the Government."53 He was writing on May 27, 1935, a day which later became known as "Black Monday." On that day, the Supreme Court handed the Roosevelt Administration three defeats, one of them especially painful. The Court limited executive control of the Federal Trade Commission, ${ }^{54}$ struck down the Lemke-Frazier Farm Bankruptcy Act, ${ }^{55}$ and, to cap it off, the National Industrial Recovery Act. ${ }^{56}$

"A good many people," Cummings observed, "are saying that either the Supreme Court was wrong, or the Constitution was wrong; and this has revived talk about Constitutional amendments or other methods" of bringing the court into line. The next two chapters contain analyses of various court-curbing proposals from court-packing to imposing a mandatory retirement age and restricting the power of judicial review. In this chapter, I focus on public opinion concerning various attempts to overturn Supreme Court decisions about economic power via constitutional amendment.

Federal Regulation of Industry and Agriculture

Following the invalidation of the NIRA, President Roosevelt held a press conference in which he criticized the Supreme Court for relegating the country "to the horse-and-buggy definition of interstate commerce." 57 He also began looking at a more permanent solution to the conflict with the Court. While he eventually settled on court-packing, he also sought advice on possible constitutional amendments from advisors, administration officials and members of Congress. One common theme discussed privately in White House debates and publicly in Congress was to increase federal regulatory power. Roosevelt expressed some interest in an amendment drafted by Senator Edward Costigan (D-CO), which empowered "Congress to legislate for the general welfare where states could not effectively do so."58

Senator Henry Ashurst (D-AZ), the chair of the Senate Judiciary Committee, introduced a more modest version of the Costigan amendment. His proposal would grant Congress the

\footnotetext{
${ }^{53}$ Shesol, Supreme Power, 138.

${ }^{54}$ Humphrey's Executor v. United States, 295 U.S. 602 (1935).

55 Louisville Bank v. Radford, 295 U.S. 555 (1935).

56 Schechter Poultry Corp. v. United States, 295 U.S. 495 (1935).

57 "Press Conference \#209," 28.

${ }^{58}$ Kyvig, Explicit and Authentic Acts, 297.
} 
"power to make laws to regulate agriculture, commerce, industry, and labor." Ashurst described the Constitution as an "instrument to defend liberty without opposing true progress. The Constitution will not be preserved by thwarting a well-defined, seasoned, sober second thought of its citizenry." 59 Ashurst's efforts were gaining momentum when the $75^{\text {th }}$ Congress convened in January 1937. House Speaker William Bankhead (D-AL) and Senate Majority Leader Joe Robinson (D-AR) both stated a desire for Congress to consider a constitutional amendment, and press reports at the time indicated the Ashurst amendment provided a more workable solution than amendments to curb the Supreme Court. ${ }^{60}$

The increasing public attention led Gallup to ask questions about this proposal on three polls between January 1936 - in the immediate aftermath of the Court's AAA decision — and March 1937—when opponents of court-packing stressed a preference for a constitutional amendment instead. Public opinion on the Ashurst amendment evolved over the 15 months between the three surveys. At first, it enjoyed the backing of only $43 \%$ of respondents. ${ }^{61}$ By the end of 1936, support was evenly split with major partisan differences. While $63.4 \%$ of Roosevelt voters backed the amendment, only $22.2 \%$ of Landon voters felt the same way. ${ }^{62}$ By March of 1937, 61.3\% of respondents endorsed the amendment, when it became modestly more popular with voters from both parties. ${ }^{63}$ As displayed on the far left of Figure 1, 78.3\% of Roosevelt voters and $34.2 \%$ of Landon voters favored Ashurst's proposal. ${ }^{64}$

\section{Minimum Wages}

President Roosevelt's ascension to the White House not only created new constitutional controversies it also reignited three old conflicts. During FDR's first term, Congress and state legislatures considered constitutional amendments that would overturn Supreme Court decisions from the Progressive Era. The first set of cases limited the power of state governments to set

59 "Ashurst Proposes Basic Law Change."

60 "Basic Law Change Gains in Congress."

${ }^{61}$ This Gallup survey was so early that only the most basic crosstabulations are available for analysis. Gallup, The Gallup Poll, 1:21.

${ }^{62}$ Gallup Organization, Poll 61.

${ }^{63}$ Gallup Organization, Poll 72.

${ }^{64}$ Except for the statistics on support for the minimum wage amendment, the data displayed in Figure 1 represent the marginal effect of 1936 vote choice in a probit model using the same control variables described earlier in this chapter. 
minimum wages for workers. The other lines of precedent restricted Congress' authority to ban child labor and tax state government bonds. ${ }^{65}$

The height of the Supreme Court's unpopularity occurred in May 1936. After beginning the year by invalidating the AAA, the Court issued yet another surprising opinion at the end of its terms, striking down a New York law providing a minimum wage for female workers. ${ }^{66}$ The case, Morehead v. New York ex rel. Tipaldo, reaffirmed a 1923 holding that minimum wage laws, even for women who were perceived as vulnerable, was beyond the power of the state. ${ }^{67}$ At the same time, the Court's recent jurisprudence allowed state governments some flexibility in responding to the exigencies of the Depression, ${ }^{68}$ so the 5-4 decision in Tipaldo shocked many observers. President Roosevelt made his first statement about the Court since his "horse and buggy" comments the previous year. Roosevelt described the Court as creating a "no-man'sland' where no government can function." The Supreme Court's approach to wage regulation was that "[a] state cannot do it and the Federal Government cannot do it."69

Criticism of the Court's ruling came from conservatives as well as liberals. The Albany Knickerbocker Press wrote that "the law that would jail any laundry-man for having any underfed horse should jail him for having an underfed [female] employee."70 Politically, the decision undermined Republican Alf Landon's campaign twin messages of respect for the Supreme Court and addressing the problems of the Great Depression through state-level solutions. ${ }^{71}$

According to a Gallup poll conducted just after the Supreme Court's ruling, Americans strongly supported amending the Constitution to provide for a minimum wage. Overall, 70\% of respondents favored the amendment, as did $84 \%$ of Democrats and $51 \%$ of Republicans. Figure

\footnotetext{
${ }^{65}$ Gallup also asked questions concerning a third type of amendment expanding federal power. On three occasions, Gallup polled support for an amendment clarifying the federal government has the power to regulate industry and agriculture. I analyze those polls in the next chapter.

${ }^{66}$ Morehead v. New York ex rel. Tipaldo, 298 U.S. 587 (1936).

${ }^{67}$ Adkins v. Children's Hospital, 261 U.S. 525 (1923).

${ }^{68}$ Home Building \& Loan Ass'n v. Blaisdell, 290 U.S. 398 (1934) (upholding a state law extending the time borrowers could repay creditors); Nebbia v. New York, 291 U.S. 502 (1934) (upholding a state law regulating the price of milk).

69 "Press Conference \#300," 1.

70 Shesol, Supreme Power, 222.

71 Shesol, 222.
} 
1 displays these results. In a follow-up question, $56 \%$ of respondents indicated a preference that the federal government possess this power, as opposed to the states. ${ }^{72}$

\section{Child Labor}

In 1916, Congress attempted to crack down on states that had refused to ban child labor. Under the prevailing understanding of federalism, states held the prerogative to regulate labor conditions, while Congress retained authority to regulate the transportation and sale of goods across state lines. The Owen-Keating Act attempted to bridge this gap by banning the interstate shipment of products produced by child labor. ${ }^{73}$ The Supreme Court struck this law down, ${ }^{74}$ as well as a subsequent federal law that attempted to tax goods made by children. ${ }^{75}$

In 1924, Congress responded a third time by proposing a constitutional amendment banning child labor. The amendment, like the earlier legislation, enjoyed broad support in Congress. Even President Calvin Coolidge - who famously said, "The chief business of America is business" ${ }^{96}$ — supported the Child Labor Amendment. ${ }^{77}$ These sentiments were not shared in many state legislatures, however. Before Roosevelt's election, only six legislatures had voted to ratify, while 38 states had rejected the amendment. An odd coalition of interests had coalesced to oppose ratification, including the Catholic Church, agricultural groups, manufacturers, and the American Liberty League. ${ }^{78}$

The 1932 election reinvigorated efforts to ban child labor through statutory and constitutional means. Many of the industry codes developed under the auspices of the National Industrial Recovery Act (NIRA) prohibited the employment of children under the age of $16 .^{79}$ Opponents of child labor also revived amendment ratification efforts to create a permanent solution to this problem. In 1933, nine legislatures approved the amendment during their regular legislative sessions, and five more did so during special sessions. Following the Supreme Court's 1935 invalidation of the NIRA, ${ }^{80}$ the amendment gained more support from both

\footnotetext{
${ }^{72}$ Gallup, The Gallup Poll, 1:28-29.

${ }^{73}$ Magliocca, "Court-Packing and the Child Labor Amendment," 462.

${ }^{74}$ Hammer v. Dagenhart, 247 U.S. 251 (1918).

${ }^{75}$ Child Labor Tax Case, 259 U.S. 20 (1922).

${ }^{76}$ As cited in Sobel, "Essays, Papers \& Addresses."

${ }^{77}$ Magliocca, "Court-Packing and the Child Labor Amendment," 463.

${ }^{78}$ Kyvig, Explicit and Authentic Acts, 301.

${ }^{79}$ Trattner, Crusade for the Children, 190-96.

${ }^{80}$ Schecter, 295 U.S.
} 
political leaders and the public. In an effort to make adoption easier, the new child labor amendments introduced in Congress after 1935 would have required ratification through state conventions, not state legislatures. ${ }^{81}$

Four questions about child labor appeared on Gallup polls from 1936 to 1937. The last child labor amendment question came on its February 3-8, 1937 survey $(\mathrm{N}=2,969)$, when the idea received support from $68.7 \%$ of respondents. There is a statistically meaningful partisan split on this issue, with $58.7 \%$ of Landon voters and $75.7 \%$ of Roosevelt voters supporting the amendment. Figure 1 visualizes these results. The other Gallup surveys that included child labor amendment questions also displayed stable, bipartisan agreement with Democrats being somewhat more supportive of banning child labor than Republicans.

Taxing State and Municipal Bonds

In 1895, the Supreme Court struck down the federal Income Tax Act as a violation of the Constitution's requirement that direct taxes be apportioned according to state population. ${ }^{82}$ The Sixteenth Amendment was ratified in 1913 to overturn the Court's decision. What this amendment left unaddressed, however, was another holding from the Pollock decision — that it was unconstitutional for the federal government to tax income gained from interest on state or municipal bonds. The Supreme Court clarified that such a tax remained unconstitutional in a 1928 decision. $^{83}$

Partially as a result of these judicial decisions, the dollar volume of municipal bonds more than quadrupled between 1913 and 1931. By the early 1930s, the value of municipal bonds represented 35\% of the national gross domestic product. ${ }^{84}$ Henry Morgenthau, Roosevelt's Treasury Secretary, estimated that eliminating this tax exemption would bring in $\$ 145$ million a year, ${ }^{85}$ a figure equal to just under two percent of the 1937 federal budget. ${ }^{86}$ Members of Congress from both parties, eager to find funding for New Deal programs, introduced 79

\footnotetext{
${ }^{81}$ The $21^{\text {st }}$ Amendment, which took effect at the beginning of the Roosevelt administration, was the only time in American history when ratification took place via state conventions.

${ }^{82}$ Pollock v. Farmers' Loan \& Trust Co., 157 U.S. 429 (1895).

${ }^{83}$ National Life Ins. Co. v. United States, 277 U.S 508 (1928).

${ }^{84}$ Joffe, "Drivers of Municipal Bond Defaults during the Great Depression," 3.

85 "Morgenthau Asks Federal Bond Tax."

${ }^{86}$ American Presidency Project, "Federal Budget Receipts and Outlays."
} 
constitutional amendments on this issue between 1932 and 1937. Andrew Mellon, who served as Treasury Secretary to Presidents Coolidge and Hoover, also favored this proposal. ${ }^{87}$

Public opinion reflected the bipartisan elite consensus on taxing income from state and municipal bonds. Gallup inquired about amending the Constitution to permit taxation of income from government bonds on its June 16-21, 1937 survey $(\mathrm{N}=2,904)$. Overall, $61.0 \%$ of respondents backed this proposal. There are no statistically meaningful differences across party affiliation: $57.2 \%$ of Landon voters favored this amendment, as did 59.2\% of Roosevelt voters. These results are displayed on the far right of Figure 1.

\section{Comparing New Deal Amendment and Policy Support}

Although Gallup surveys only provide glimpses of public attitudes towards a few of the many constitutional amendments proposed during the 1930s, the pattern that seems to emerge is that a majority of Americans from both parties thought the Constitution needed to reflect the new realities of federal and state regulatory power. To broaden this picture, I measured support for New Deal laws across party lines using statistical models of responses to Gallup questions between 1936 and 1938. Figure 2 displays this data. ${ }^{88}$

Four of these policies - the National Industrial Recovery Act, the Agricultural Adjustment Act, the Securities Act, and the taxation of state and local bonds- - had been declared unconstitutional by the time Gallup administered these surveys. The remaining laws-Social Security, the National Labor Relations Act, and the Fair Labor Standards Act-would most likely have been struck down, had the Court not reversed course in 1937. Each of the policies displayed in Figure 2 enjoyed the support of a majority of respondents overall. While the NIRA was particularly unpopular with Republicans, a majority of GOP voters backed every other policy. As to be expected, Roosevelt voters favored every policy at substantially higher rates than Landon voters. That so many citizens supported policies whose constitutionality the Supreme Court had called into question suggests voters were willing to disagree with the Court.

Many of these policies address the same issues as the constitutional amendments described in the previous section. For example, the Ashurst amendment would have overturned

\footnotetext{
87 "Lonergan Calls on Morgenthau to State Whether Treasury Wants Legislation Legislation Now."

${ }^{88}$ Specifically, Figure 2 displays the marginal effect of 1936 vote choice on a probit model of support for the law in question, controlling for the same demographic factors described earlier in this chapter.
} 
the Court's invalidation of the NIRA and the AAA. Both the NIRA and the FLSA banned child labor and provided minimum wages for female (and male) workers. Overall, support for New Deal policies was higher than their corresponding constitutional amendment. It is difficult to surmise what, if anything, this difference means. President Roosevelt ultimately opposed constitutional amendments because he believed the Constitution, as written, provided the federal government sufficient power. The real problem, he believed, was how the Court was interpreting the Constitution. It may also be the case that citizens are more nervous changing the Constitution than changing ordinary law. Empirically, political scientists have found that "there is something about constitutions per se that biases individuals against proposals that would result in constitutional change" - even amendments consistent with their policy preferences. ${ }^{89}$

\section{Conclusion}

Political scientists and law professors view the New Deal through very different perspectives. In this chapter, I have made a first attempt at evaluating different theories of political realignment and constitutional development. Using direct comparisons of economicand policy-based models of New Deal support, I find little evidence that economic performance was the primary driver of Roosevelt's popularity. Support for New Deal policies provides a more robust explanation, which may explain why conservative members of Congress supported the Fair Labor Standards Act, a major liberal policy, in the midst of the Roosevelt Recession.

Despite the fact that the debate on the FLSA took place a year after the Supreme Court had become more reliably liberal, supporters and opponents in the House routinely made constitutional arguments. This rhetoric may have been primarily directed at persuading their colleagues, but it may also be the case that constitutional considerations permeated the larger public understanding of New Deal economic policy. According to Gallup surveys, New Deal laws as well amendments that would protect the constitutional status of these policies enjoyed strong support on a bipartisan basis.

The fact that constitutional amendments received so much consideration, in public and congressional debates, is an unavoidable byproduct of the conflict between Franklin Roosevelt and the Supreme Court. None of the amendments discussed in this chapter came to fruition, in

\footnotetext{
${ }^{89}$ Zink and Dawes, "The Dead Hand of the Past?," 537.
} 
part, because Roosevelt chose another method of dealing with judicial recalcitrance: courtpacking. In so doing, he unleashed another intense public debate, the dynamics of which I analyze in the next chapter. 
Tables and Figures

Table 3.1. Question Wording

Question Type Question Wording

\section{Gallup Poll 53, 9/28/36 - 10/2/36}

Pres. vote Which candidate do you prefer for President?

Policy Do you favor the compulsory old-age insurance plan, starting January first, which requires employers and employees to make equal monthly contributions?

Policy Would you favor government loans, on a long time and easy basis, to enable farm tenants to buy farms they now rent?

Gallup Poll 56, 11/6/36 - 11/11/36

Pres. approval Should President Roosevelt's second administration be more liberal, more conservative, or about the same as his first?

Pres. vote Should President Roosevelt be a candidate for a third term in 1940?

Economic Do you think there will be another serious depression?

Policy Do you think the President and the Congress should seek to enact a second NRA?

Policy Do you favor the compulsory Old Age Insurance Plan, starting in January, which requires employers and workers to contribute equally towards workers, pensions?

Gallup Poll 69, 2/17/37 - 2/22/36

Pres. vote If the November election were held today, how would you vote?

Policy Would you like to see the AAA (Agricultural Adjustment Administration) revived?

Policy Are you in favor of President Roosevelt's proposal to reorganize the Supreme Court?

Policy Do you think Congress and the President should seek to enact a second NRA (National Recovery Act)?

Gallup Poll 74, 3/17/37 - 3/22/37

Pres. vote Would you favor a third-term for President Roosevelt if he ran again in 1940?

Economic Do you think it would be a good thing (inflation)?

Policy $\quad$ Are you in favor of President Roosevelt's plan regarding the Supreme Court?

Policy Do you believe the Federal Government should further reduce relief expenditures at this time?

Gallup Poll 101, 10/20/37 - 10/25/37

Pres. vote If last November's election were being held over again today, which candidate would you vote for now?

Economic Do you expect general business conditions will be better or worse in the next six months?

Policy Do you think government expenditures should be increased or decreased on the following...unemployment relief?

Policy Do you think government expenditures should be increased or decreased on the following...farm benefits?

Gallup Poll 106, 12/15/37 - 12/20/37

Pres. vote If the 1936 presidential election were being held over again today, which candidate would you vote for now?

Economic Do you expect general business conditions will be better or worse during the next six months? 
Gallup Poll 109, 1/20/38 - 1/25/38

Pres. vote

Pres. vote

Cong. vote

Economic

Policy

Policy

Policy

\section{Gallup Poll 114, 3/10/38 - 3/15/38}

Pres. vote

Cong. vote

Would you favor a third term for President Roosevelt?

Pres. approval

If you were voting for Congressman today, would you be most likely to vote for the Republican, the Democratic, or Third Party candidate?

Economic

Policy

Policy

Are you for or against Roosevelt today?

Do you expect general business conditions will be better or worse during the next six months?

Do you think the President of the United States should have more power or less power than he now has?

\section{Gallup Poll 117, 4/2/38 - 4/7/38}

Pres. vote

Do you favor a third term for President Roosevelt?

Pres. approval

Economic

Policy

Are you for or against Roosevelt today?

\section{Gallup Poll 127, 7/4/38 - 7/9/38}

Do you think the price of most of the articles you buy will be higher or lower three months from now?

\section{Pres. vote}

Cong. vote

Pres. approval

Policy

Policy

Policy

Policy

Policy
If President Roosevelt runs for a third term will you vote for him?

If you were voting for Congressman today, would you be most likely to vote for the Republican, the Democratic, or the candidate of some other party?

Are you for or against (President) Roosevelt today?

Do you think it is the government's responsibility to pay the living expenses of needy people who are out of work?

Do you approve of the federal law which regulates minimum and maximum hours?

Do you favor the Federal government's spending program to help get business out of its present slump?

Do you approve of the present Social Security laws that provide old age pensions and unemployment insurance?

Do you approve of federal regulation of the securities exchanges? 


\section{Gallup Poll 128, 7/15/38 - 7/20/38}

Cong. vote If you were voting for Congress today, would you be most likely to vote for the Republican, Democratic or some other party candidate?

Pres. approval Are you for or against Roosevelt today?

Economic Are you better off or worse off today than you were a year ago?

Policy Did you favor the reorganization bill?

Policy Did you favor the President's plan to enlarge the Supreme Court last year?

\section{Gallup Poll 135, 10/10/38 - 10/15/38}

Pres. vote Do you favor a third term for President (Franklin) Roosevelt?

Cong. vote If you were voting for Congressman today would you be most likely to vote for the Republican candidate (named), the Democratic

candidate (named), or the candidate of some other party?

Pres. approval In general, do you approve or disapprove of Franklin Roosevelt as President today?

Policy Are you in favor of labor unions?

\section{Gallup Poll 142, 12/25/38 - 12/30/38}

Pres. approval In general, do you approve or disapprove of Franklin Roosevelt as President today?

Policy Do you think the Federal Government is spending too much, too little, or about the right amount of money at this time?

Policy Should Congress create a new Cabinet Department of Public Welfare to handle public health, education and welfare?

Policy Should Congress give the President power to appoint six executive assistants with a salary of $\$ 10,000$ a year each?

\section{Gallup Poll 145, 1/22/39 - 1/27/39}

Pres. approval In general, are you satisfied today with Roosevelt as President?

Policy Should people who own United States government bonds or state or municipal bonds have to pay federal income taxes on their incomes from these securities?

Policy The present Old-Age Pension and Unemployment Insurance Act does not cover household help, bank workers, sailors, farmhands and employees of charitable

Policy institutions. Do you think the law should be extended to include these workers?

Gallup Poll 151, 3/10/39 - 3/15/39

Pres. approval In general, do you approve or disapprove of Franklin Roosevelt as President today?

Economic Considering your income and cost of living are you better off today than you were a year ago?

Policy It has been suggested that the Federal Government cut all expenditures--including relief, farm aid, pensions, national defense and ordinary government running

\section{Gallup Poll 166, 8/10-39 - 8/15/39}

Pres. approval In general, do you approve or disapprove of Franklin Roosevelt as President? 
Cong. approval In general, do you think the present Congress has done a good job or a poor job?

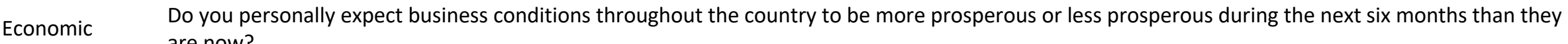
are now?

Policy Are you in favor of labor unions?

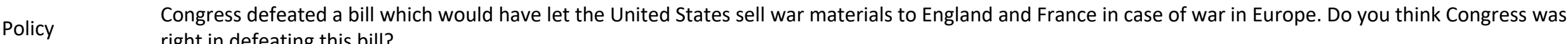
right in defeating this bill?

\section{Gallup Poll 176, 11/10/39 - 11/15/39}

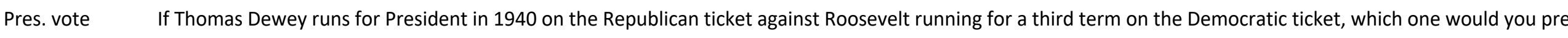

Pres. approval In general, do you approve or disapprove today of Roosevelt as President?

Economic Considering your income and cost of living, do you feel you are better off today than you were a year ago?

Policy Do you believe in government old-age pensions?

Policy Do you think pensions should be given to old people who are in need, or to all old people?

Gallup Poll 204, 8/2/40 - 8/7/40

Pres. vote If the Presidential election were held today, would you vote for the Republican candidate, Willkie, or the Democratic candidate, Roosevelt? President Roosevelt has asked Congress for authority to call the National Guard for one year of military training. Do you approve or disapprove of calling the National Guard for one year of training?

Policy Do you think the government should own the electric companies?

Policy Do you think the United States should change the Neutrality Law to permit us to send food to England in our own ships?

Gallup Poll 215, 10/11/40 - 10/16/40

Pres. vote If the presidential election were held today, would you vote for Franklin Roosevelt or Wendell Willkie?

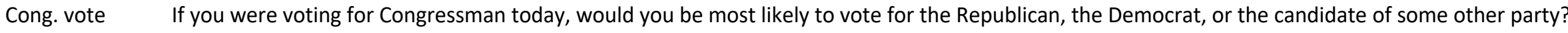

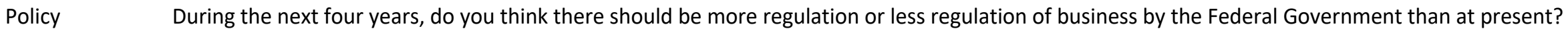

Policy Should the Neutrality Law be changed so that American ships can carry war supplies to England?

\section{Constitutional Amendment Questions}

Do you favor an amendment to the Constitution to regulate minimum wages?

Do you favor an amendment to the Constitution giving Congress the power to limit, regulate, and prohibit the labor of persons under eighteen?

Would you favor an amendment to the Constitution giving Congress greater power to regulate industry and agriculture?

Would you favor an amendment to the Constitution making the income from government bonds taxable? 
Table 3.2. Comparing Performance of Policy Attitude and Economic Voting Models

\begin{tabular}{lcccc} 
& & \multicolumn{2}{c}{ Policy $\mathrm{R}^{2}>$} \\
Model Type & N & Econ. $\mathrm{R}^{2}$ & \\
Subjective Economic Perceptions & 43 & $62.8 \%$ & \\
Objective Economic Indicators & 42 & $81.0 \%$ & $*$ \\
Presidential Vote & 39 & $71.8 \%$ & $*$ \\
Non-Southern Congressional Vote & 19 & $57.9 \%$ & \\
Presidential Approval Rating & 27 & $81.5 \%$ & $*$ \\
Overall & 85 & $71.8 \%$ & $*$
\end{tabular}

$* p<0.05$ 
Figure 1. Approval of Proposed Constitutional Amendments with 95\% Confidence Intervals

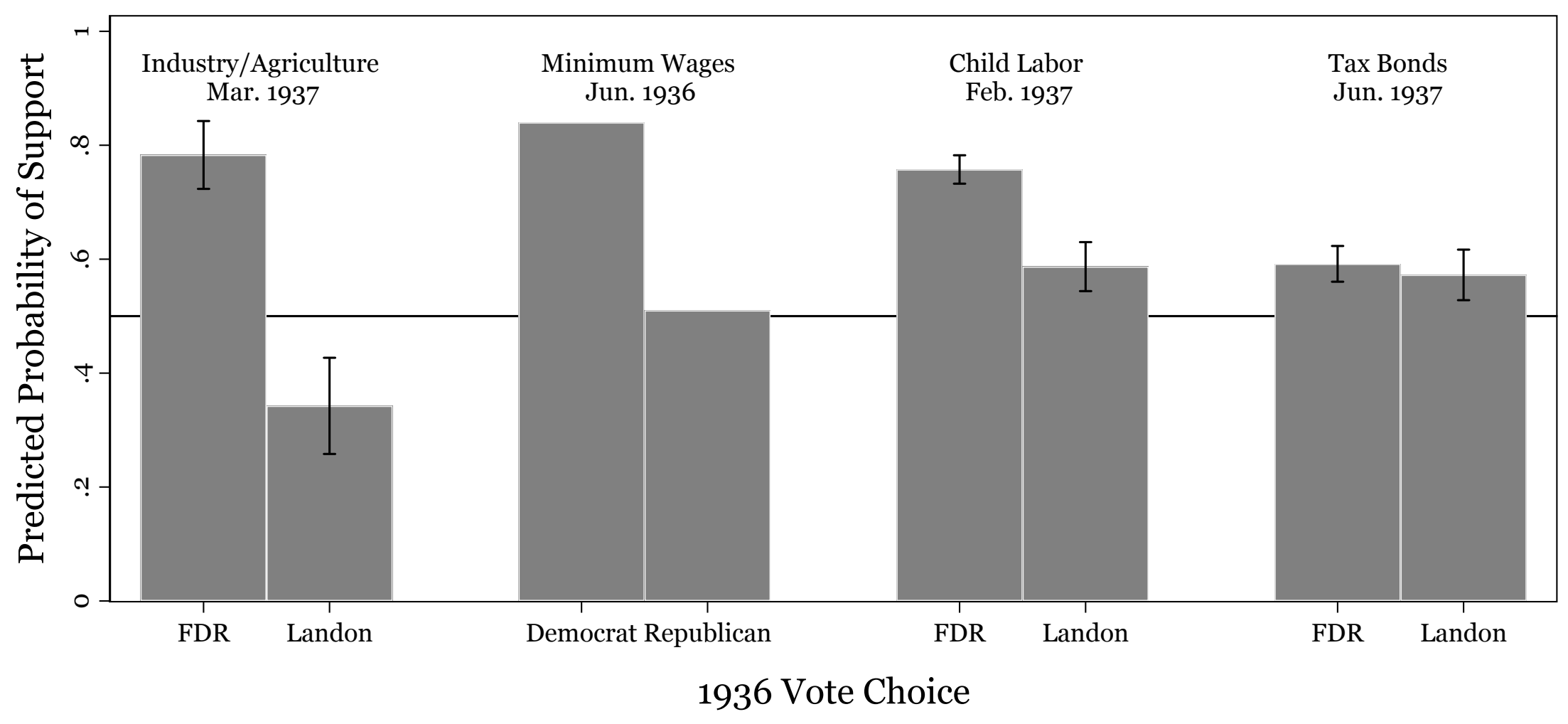


Figure 2. Approval of New Deal Policies

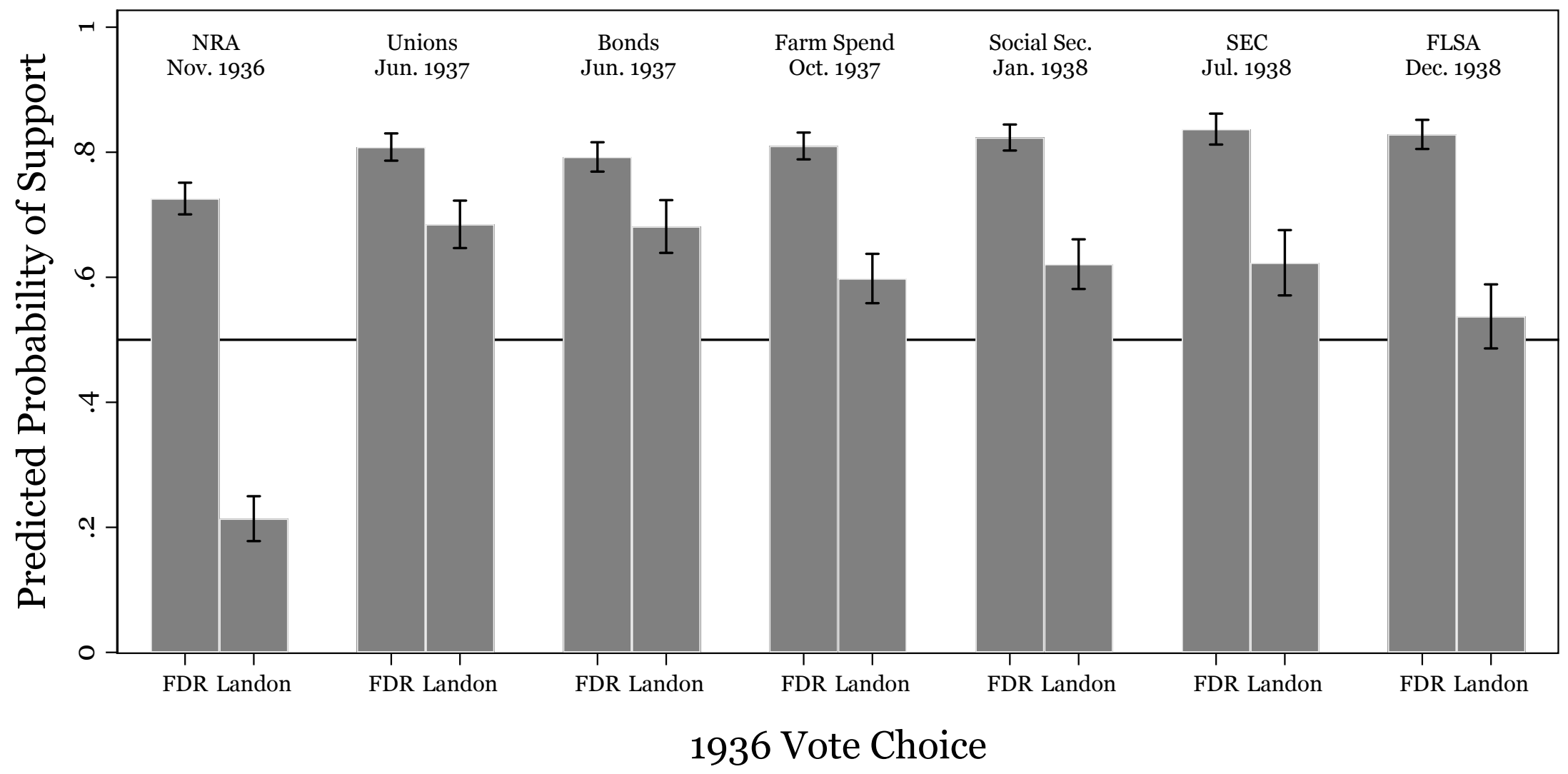




\section{References}

Achen, Christopher H., and Larry M. Bartels. Democracy for Realists: Why Elections Do Not Produce Responsive Government. Princeton, NJ: Princeton University Press, 2017.

Ackerman, Bruce. "A Generation of Betrayal." Fordham Law Review 65, no. 4 (1997): 1519-36. We the People: Foundations. Cambridge, MA: Harvard University Press, 1991.

. We the People: Transformations. Cambridge, MA: Harvard University Press, 1998.

American Presidency Project. "Federal Budget Receipts and Outlays," 2012. https://www.presidency.ucsb.edu/statistics/data/federal-budget-receipts-and-outlays.

“Ashurst Proposes Basic Law Change.” New York Times, June 8, 1936. http://timesmachine.nytimes.com/timesmachine/1936/06/09/87949102.html.

"Basic Law Change Gains in Congress." New York Times, January 8, 1937. http://timesmachine.nytimes.com/timesmachine/1937/01/08/94317151.html.

Berinsky, Adam J. "American Public Opinion in the 1930s and 1940s: The Analysis of QuotaControlled Sample Survey Data." Public Opinion Quarterly 70, no. 4 (2006): 499-529.

Berinsky, Adam J., Eleanor Neff Powell, Eric Schickler, and Ian Brett Yohai. "Revisiting Public Opinion in the 1930s and 1940s." PS: Political Science \& Politics 44, no. 3 (2011): 515 520.

Burnham, Walter Dean. Critical Elections and the Mainsprings of American Politics. New York: Norton, 1970.

Campbell, Angus, University of Michigan Survey Research Center, Philip E. Converse, Warren E. Miller, and Donald E. Stokes. The American Voter. New York: John Wiley \& Sons, 1960.

Caughey, Devin, Adam J. Berinsky, Sara Chatfield, Erin Hartman, Eric Schickler, and Jasjeet S. Sekhon. "Population Estimation and Calibration Weighting for Nonresponse and Sampling Bias: An Application to Quota-Sampled Opinion Polls, 1936-53,” 2017. https://www.dropbox.com/s/qnol9sffrb2bci1/CaugheyEtAl-Weights.pdf?dl=0.

Caughey, Devin, Michael C. Dougal, and Eric Schickler. "Policy and Performance in the New Deal Realignment: Evidence from Old Data and New Methods." Journal of Politics 82, no. 2 (2020): 494-508.

Child Labor Tax Case, 259 U.S. 20 (Supreme Court 1922).

Congressional Record. Vol. 83. Washington, D.C.: Government Printing Office, 1938. https://www.govinfo.gov/app/details/GPO-CRECB-1938-pt7-v83/.

Cooper, Melissa. "Reframing Eleanor Roosevelt's Influence in the 1930s Anti-Lynching Movement around a 'New Philosophy of Government." European Journal of American Studies 12, no. 1 (March 7, 2017): 1-15.

Corwin, Edward Samuel. Constitutional Revolution, Ltd. Literary Licensing, LLC, 2012.

Davis, Otto A., Melvin J. Hinich, and Peter C. Ordeshook. "An Expository Development of a Mathematical Model of the Electoral Process." American Political Science Review 64, no. 2 (June 1970): 426-48.

Douglas, Paul H., and Joseph Hackman. "The Fair Labor Standards Act of 1938." Political Science Quarterly 53, no. 4 (1938): 491-515.

Fiorina, Morris P. Retrospective Voting in American National Elections. New Haven, CT: Yale University Press, 1981.

Gallup, George. The Gallup Poll: Public Opinion, 1935-1971. Vol. 1. New York: Random House, 1972. 
Gallup Organization. Poll 61. Distributed by Roper Center for Public Opinion Research, Cornell University, December 16-21, 1936, n.d.

—. Poll 72. Distributed by Roper Center for Public Opinion Research, Cornell University, March 3-8, 1937, n.d.

- Poll 118. Distributed by Roper Center for Public Opinion Research, Cornell University, April 8-13, 1938, n.d.

Jefferson, Renee Knake, and Hannah Brenner Johnson. Shortlisted: Women in the Shadows of the Supreme Court. New York: NYU Press, 2020.

Joffe, Marc D. "Drivers of Municipal Bond Defaults during the Great Depression.” SSRN Scholarly Paper. Rochester, NY: Social Science Research Network, December 14, 2012. https://papers.ssrn.com/abstract=2189889.

Key, V. O. Jr. “A Theory of Critical Elections.” Journal of Politics 17, no. 1 (February 1, 1955): $3-18$.

Key, V.O. Jr. The Responsible Electorate: Rationality in Presidential Voting 1936-1960. Cambridge, MA: Harvard University Press, 1960.

Kinder, Donald R., and D. Roderick Kiewiet. "Sociotropic Politics: The American Case." British Journal of Political Science 11, no. 2 (1981): 129-61.

Kramer, Gerald H. "The Ecological Fallacy Revisited: Aggregate- versus Individual-Level Findings on Economics and Elections, and Sociotropic Voting." The American Political Science Review 77, no. 1 (1983): 92-111.

Kyvig, David E. Explicit and Authentic Acts: Amending the U. S. Constitution, 1776-2015. Lawrence, KS: University of Kansas Press, 2016.

Ladd, Everett Carll, and Charles D. Hadley. Transformations of the American Party System: Political Coalitions from the New Deal to the 1970s. New York: Norton, 1975.

Laski, Harold J. "The Roosevelt Experiment." The Atlantic, February 1934. https://www.theatlantic.com/magazine/archive/1934/02/the-rooseveltexperiment/307116/.

Lewis-Beck, Michael S. "Pocketbook Voting in U.S. National Election Studies: Fact or Artifact?" American Journal of Political Science 29, no. 2 (1985): 348-56.

"Lonergan Calls on Morgenthau to State Whether Treasury Wants Legislation Legislation Now." New York Times, June 5, 1937.

Magliocca, Gerard N. "Court-Packing and the Child Labor Amendment." Constitutional Commentary 27, no. 3 (2011): 455-86.

"Morgenthau Asks Federal Bond Tax." New York Times. March 9, 1934.

National Life Ins. Co. v. United States, 277 U.S. 508 (Supreme Court 1928).

Norpoth, Helmut, Andrew H. Sidman, and Clara H. Suong. "Polls and Elections: The New Deal Realignment in Real Time.” Presidential Studies Quarterly 43, no. 1 (March 1, 2013): 146.

Patterson, James T. Congressional Conservatism and the New Deal: The Growth of the Conservative Coalition in Congress, 1933-1939. Lexington, KY: University of Kentucky Press, 1967.

Pollock v. Farmers' Loan \& Trust Co., 157 U.S. 429 (Supreme Court 1895).

“Press Conference \#209," May 31, 1935. Press Conference Transcripts. Franklin D. Roosevelt Presidential Library, Poughkeepsie, New York. http://www.fdrlibrary.marist.edu/_resources/images/pc/pc0022.pdf. 
“Press Conference \#300,” March 11, 1937. Press Conference Transcripts. Franklin D. Roosevelt Presidential Library, Poughkeepsie, New York. http://www.fdrlibrary.marist.edu/_resources/images/pc/pc0036.pdf.

Reilley, Katie. "Rick Perry Could Lead the Government Agency He Once Forgot Existed." Time, December 13, 2016. https://time.com/4598910/rick-perry-department-energy-oops-gaffe/.

Schlesinger, Arthur M., Jr. The Politics of Upheaval. Boston: Houghton Mifflin Harcourt, 1960.

Shesol, Jeff. Supreme Power: Franklin Roosevelt vs. the Supreme Court. New York: W. W. Norton \& Company, 2011.

Sobel, Robert. "Essays, Papers \& Addresses.” Calvin Coolidge Presidential Foundation, 1988. https://coolidgefoundation.org/resources/essays-papers-addresses-35/.

Soroka, Stuart N., Dominik A. Stecula, and Christopher Wlezien. "It's (Change in) the (Future) Economy, Stupid: Economic Indicators, the Media, and Public Opinion." American Journal of Political Science 59, no. 2 (2015): 457-74.

Sparrow, Bartholomew H. The Insular Cases and the Emergence of American Empire. Lawrence, KS: University Press of Kansas, 2006.

Stokes, Donald E. "Spatial Models of Party Competition." American Political Science Review 57, no. 2 (June 1963): 368-77.

Sundquist, James L. Dynamics of the Party System: Alignment and Realignment of Political Parties in the United States. 2nd ed. Washington, D.C: Brookings Institution Press, 1983.

“The Republicans: A Dangerous Game." The Economist, November 5, 2011. https://www.economist.com/briefing/2011/11/05/a-dangerous-game.

These Are Our Lives: As Told to by the People and Written by Members of the Federal Writers' Project of the Works Progress Administration in North Carolina, Tennnesse, and Georgia. New York: W. W. Norton and Company, 1975.

Trattner, Walter I. Crusade for the Children: A History of the National Child Labor Committee and Child Labor Reform in America. Chicago: Quadrangle Books, 1970.

Waiwood, Patricia. "Recession of 1937-38." Federal Reserve History (blog), November 22, 2013. https://www.federalreservehistory.org/essays/recession_of_1937_38.

Zink, James R., and Christopher T. Dawes. "The Dead Hand of the Past? Toward an Understanding of 'Constitutional Veneration."' Political Behavior 38, no. 3 (2016): 53560. 